\title{
The epiphyte Microcladia coulteri (Rhodophyta): changes in population structure with spatial and temporal variation in availability of host species
}

\author{
G. A. Kendrick*, M. W. Hawkes** \\ Department of Botany, University of British Columbia, Vancouver, British Columbia, Canada V6T 2B1
}

\begin{abstract}
A comparison of the population structures of the epiphyte Microcladia coulteri and its 3 host species, Prionitis lanceolata, Iridea cordata and Odonthalia floccosa, was made at Beaver Point, Saltspring Island, British Columbia. The 3 host species had distinct seasonal patterns in density and size class distribution. Principal components analysis (PCA) and analysis of variance (ANOVA) were utilized to partition the variation in epiphyte population structure into components due to differences in season, host species, size of host thalli, host reproductive status, and host spatial distribution. Small percentages of total determined variation were accounted for by seasonality in the abundance of size class and reproductive components of the epiphyte population, and by distribution of the epiphyte between host species. Larger percentages were due to fluctuations in size of host thalli and spatial variation in availability of host substrata. Persistence of temporally and spatially stable populations of $M$. coulteri was due to differential use of available host substrata combined with continuous recruitment of the epiphyte.
\end{abstract}

\section{INTRODUCTION}

Epiphytes constitute a significant component of nearshore benthic algal communities (Ballantine \& Humm 1975, Harlin 1980, Whittick 1983). Previous studies of population structure in benthic (Hansen \& Doyle 1976, Norall et al. 1981, Kain 1982, De Wreede 1984, Hannach \& Santelices 1985) and epiphytic algal communities (Kain 1982, Whittick 1983) have concentrated on individual species with little reference to interactions between species. If epiphyte populations are to persist then some coupling of their growth and reproduction with colonizable host substratum must occur.

This article describes the spatial and temporal variation in population structure of the epiphyte Microcladia coulteri and its 3 host species: Prionitis lanceolata, Iridea cordata, and Odonthalia floccosa. It also analyses within- and between-host species differences in epiphyte population structure as compared with host

\footnotetext{
- Present address: Charles Darwin Research Station, c/o Fundacion Darwin para las Islas Galapagos, Casilla 3891. Quito, Ecuador

- To whom reprint requests should be addressed
}

species size, reproductive status, and spatial distribution.

Microcladia coulteri grows epiphytically on large foliose red algae and occasionally on brown algae in the lower intertidal and upper subtidal zones of the Pacific coast of North America (Abbott \& Hollenberg 1976). It is found from Baja California, Mexico, to northern Vancouver Island, British Columbia (Abbott \& Hollenberg 1976, Scagel et al. 1986). M. coulteri has been reported on species of Prionitis, Gigartina, Odonthalia and Iridea in the Strait of Georgia, British Columbia, the general location of this study. Initial investigations at the study location indicated that Gigartina was not a major component of the intertidal community $(<1$ thallus $\mathrm{m}^{-2}$ ). As $M$. coulteri occurs on a variety of host species, the importance of host population structure (availability of substrata) on persistence of epiphyte populations can be studied.

\section{METHODS}

The study was carried out at Beaver Point on Saltspring Island, British Columbia $\left(48^{\circ} 47^{\prime} \mathrm{N}, 123^{\circ} 22^{\prime} \mathrm{W}\right)$, where there were extensive populations of the host 
species, Prionitis lanceolata, Iridea cordata and Odonthalia floccosa. These were found to be vertically restricted to a 1 to $2 \mathrm{~m}$ band in the low intertidal and upper subtidal, exposed only during spring tides. A permanent transect, $50 \mathrm{~m}$ in length, was located within this band. Surveys for subtidal populations of Microcladia coulteri were made in July, October and December 1984 and February and April 1985 but none were found.

Each month, all host thalli were harvested and the density of each host species determined in 8 random $0.25 \mathrm{~m}^{2}$ quadrats along the transect. The locations of the quadrats were determined using a random numbers table (for $N=100$; Lewis 1966). Sampling was without replacement and performed using SCUBA and snorkel. The sampling design was nested with 2 placements for each location. The standard error of sampling was very large indicating a clumped (contagious) distribution for the host species (Zar 1974).

From each quadrat, random subsamples (to avoid size bias) of 10 thalli of each host species were taken and the population structures of epiphyte and host species were summarized within size classes. Epiphyte size classes were based on 2 criteria: height of main axis and presence of reproductive structures. Three size classes (height) of epiphytes were recognized: Size Class $1,<8 \mathrm{~mm}$, non-reproductive; Size Class 2,8 to $20 \mathrm{~mm}$, reproductive; Size Class $3,>20 \mathrm{~mm}$, reproductive. Reproductive plants were recorded as spermatangial, carposporangial or tetrasporangial thalli. The carposporangial thalli were used to indicate syngamy; it was assumed that apomixis by apogamy was not occurring.

Following removal of all epiphytes the host plants were wet weighed and sectioned for determination of size classes and reproductive status. One size class distribution was used for all host species examined to allow a comparison of substratum availability. Size classes were based on wet weight and were those determined by Hansen \& Doyle (1976) for Iridea cordata on the central Californian coast. The 6 size classes (wet weight) were: Size Class $1,<1.0 \mathrm{~g}$ i Size Class 2 , 1.1 to $2.0 \mathrm{~g}$; Size Class 3, 2.1 to $5.0 \mathrm{~g}$; Size Class 4, 5.1 to $10.0 \mathrm{~g}$; Size Class 5, 10.1 to $15.0 \mathrm{~g}$; Size Class 6. $>15.1 \mathrm{~g}$.

Size class distributions of Microcladia coulteri on Prionitis lanceolata $(\mathrm{N}=635)$ were examined for univariate (Zar 1974) and multivariate normality (Campbell 1980). This indicated that the data required a $4 \overline{X+1}$ transformation before proceeding with principal components analysis (PCA) based on the correlation matrix $[R]$, and analysis of variance (ANOVA), as they are more robust when the normal probability distribution is not violated.

Component scores from the PCA were analyzed in a nested analysis of variance (ANOVA). All components whose eigenvalues were less than 1,0 were eliminated from further analysis on the grounds that they accounted for less of the total variation than any of the original variables (Pocock \& Wisharf 1969). The first 3 PCA axes were used for the ANOVA. The model used was:

$\mathrm{Y} 1, \mathrm{Y} 2, \mathrm{Y} 3=\mathrm{A}+\mathrm{B}(\mathrm{A})+\mathrm{C}(\mathrm{AB})+\mathrm{D}(\mathrm{AB})+\mathrm{F}(\mathrm{AB})+\mathrm{E}$ where $\mathrm{Yn}=\mathrm{PCA}$ axis $\mathrm{n} ; \mathrm{A}=$ time of year; $\mathrm{B}=$ species of host; $C=$ size class of host $; D=$ reproductive status of host; $F=$ location along transect; $E=$ error.

\section{RESULTS}

\section{Host species}

Odonthalia floccosa showed the greatest seasonal variation in density of the 3 host species (Fig. 1). It occurred at higher densities during summer (600 to 800 thalli $\mathrm{m}^{-2} \mathrm{mo}^{-1}$ recorded from March to July), decreased dramatically (approximately 5-fold: 120 thalli $\mathrm{m}^{-2}$ for November) during late autumn and winter, and in early spring increased to levels similar to the previous summer. Larger thalli (Size Class 3 ) of $O$. floccosa

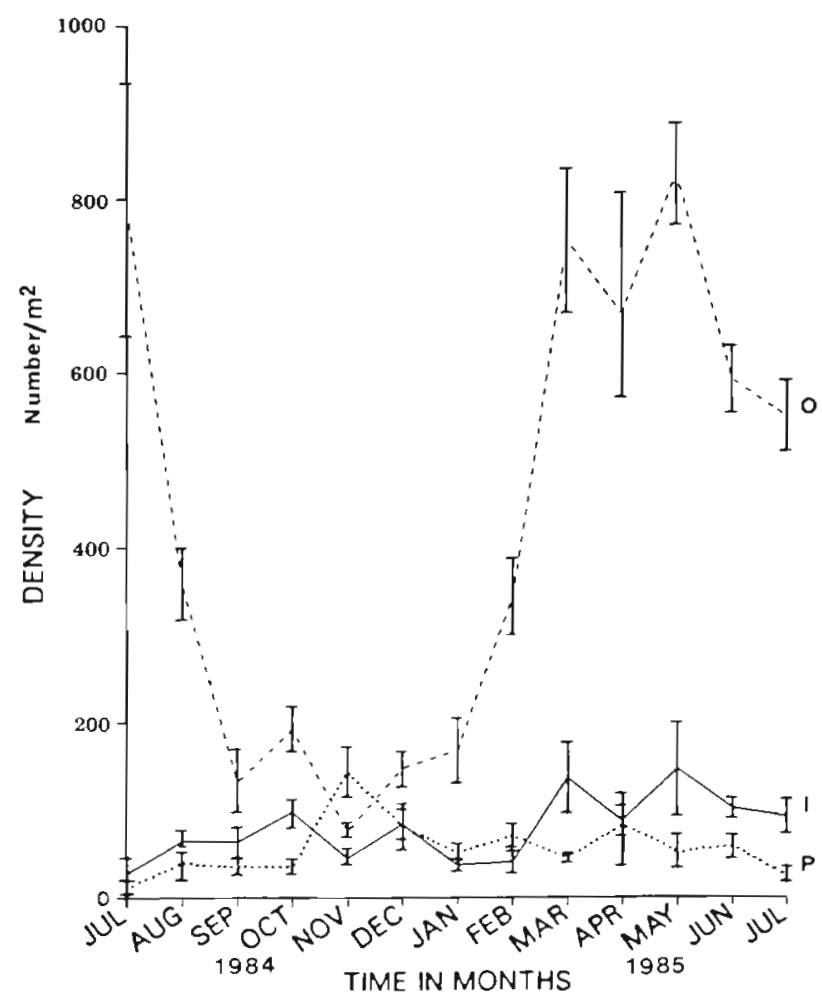

Fig. 1. Change in density of erect host thalli per $\mathrm{m}^{2}$ during the sampling period, July 1984 to July 1985, with error bars ( $N=$ 80). I: Iridea cordata; O: Odonthalia floccosa; P: Prionitis lanceolata 


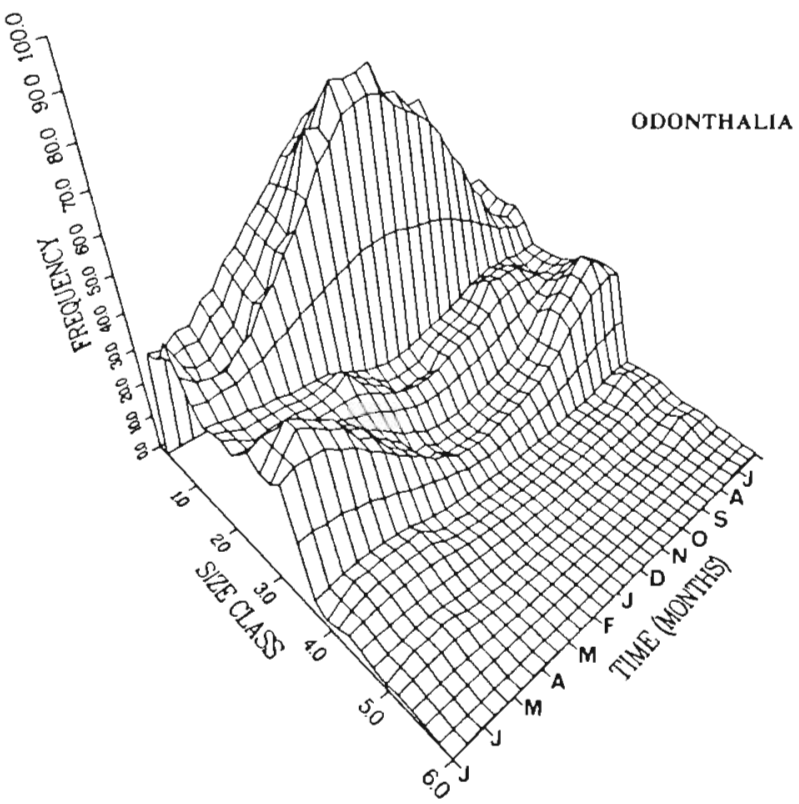

Fig. 2. Odonthalia floccosa. Size class distribution (\% trequency) during the sampling period. Time (mo) from July (J) 1984 to July 1985; size classes from 1 (smallest) to 6 (largest)
(Fig. 2) were more abundant during summer, whilst smaller thalli (Size Class 1) were predominant during winter. Tetrasporangial thalli (Table 1) occurred mainly in the spring and summer. Tetrasporangial and carposporangial thalli were larger during summer (May to July).

Iridea cordata was less abundant than Odonthalia floccosa and varied in density from 20 to 160 thalli $\mathrm{m}^{-2}$ with no apparent seasonal pattern (Fig. 1) other than an early spring increase in 1985. Larger size classes of $I$. cordata were more abundant in summer than in winter (Fig. 3). Tetrasporangial thalli (Table 1) occurred in smaller percentages in summer (June, July) and late winter (February, March) and greater percentages in autumn (September to October). Carposporangial thalli occurred in smaller percentages during spring and summer and dominated the autumn and winter populations. Larger reproductive thalli were abundant during spring, summer and early autumn (Size Classes 4, 5 and 6) and smaller thalli in the late autumn and winter. Reproductive phases in the size classes of $I$. cordata changed from larger to smaller thalli indicating that

Table 1. Percentage of tetrasporangial and carposporangial thalli in each size class (1 to 6) and for total thalli sampled from the host species Prionitis lanceolata, Odonthalia floccosa, and Iridea cordata over the sampling period, July 1984 to July 1985

\begin{tabular}{|c|c|c|c|c|c|c|c|c|c|c|c|c|c|c|c|c|c|c|c|c|c|}
\hline \multirow[b]{2}{*}{ Month } & \multicolumn{7}{|c|}{ Iridea cordata } & \multicolumn{7}{|c|}{ Odonthalia floccosa } & \multicolumn{7}{|c|}{ Prionitis lanceolata } \\
\hline & 1 & 2 & 3 & 4 & 5 & 6 & Tot. & 1 & 2 & 3 & 4 & 5 & 6 & Tot. & 1 & 2 & 3 & 4 & 5 & 6 & Tot. \\
\hline \multicolumn{22}{|c|}{ Tetrasporangial thalli } \\
\hline July & - & 2 & - & 4 & 2 & 2 & 10 & 6 & 7 & 10 & 6 & 1 & 1 & 31 & - & - & - & - & - & - & - \\
\hline August & - & 1 & 1 & 7 & - & 1 & 10 & 6 & 4 & 4 & - & - & - & 14 & - & - & - & - & - & - & - \\
\hline September & 1 & - & 5 & 7 & 3 & 9 & 25 & - & 1 & 1 & - & - & - & 2 & 15 & - & 5 & - & - & - & 20 \\
\hline October & 1 & 4 & 12 & 8 & 5 & - & 30 & - & 1 & - & - & - & - & 1 & 10 & 15 & - & - & - & - & 25 \\
\hline November & - & - & 8 & 12 & 3 & 4 & 27 & - & - & - & - & - & - & - & 7 & 3 & 7 & - & - & - & 17 \\
\hline December & 4 & 4 & 7 & 1 & 1 & 1 & 18 & - & - & - & - & - & - & - & 5 & 6 & 5 & - & - & - & 16 \\
\hline January & 1 & 4 & 1 & 9 & - & - & 15 & - & - & - & - & - & - & - & 11 & 3 & - & - & - & - & 14 \\
\hline February & 1 & 5 & 1 & 1 & - & - & 8 & 22 & 6 & - & - & - & - & 28 & 9 & 4 & - & - & - & - & 13 \\
\hline March & - & 1 & 1 & 4 & - & 1 & 7 & 1 & 9 & 1 & - & - & - & 11 & 18 & 6 & 1 & - & 1 & - & 26 \\
\hline April & - & - & - & 1 & 2 & 9 & 12 & 25 & 1 & 6 & 4 & - & 1 & 37 & 8 & 5 & 7 & 1 & - & - & 21 \\
\hline May & - & - & - & 8 & 3 & 15 & 26 & 1 & 6 & 2 & 7 & - & - & 16 & 13 & 3 & 5 & - & 1 & - & 22 \\
\hline June & - & 1 & 1 & 5 & 1 & 2 & 10 & 5 & 6 & 9 & 5 & 1 & 1 & 27 & 3 & - & 8 & - & - & - & 11 \\
\hline July & 1 & 1 & 1 & 9 & 2 & 2 & 16 & 6 & 4 & 5 & - & - & - & 15 & 1 & - & - & - & - & - & 1 \\
\hline \multicolumn{22}{|c|}{ Carposporangial thalli } \\
\hline July & - & - & - & - & 4 & 4 & 8 & 8 & 7 & 23 & 4 & 3 & - & 45 & - & 5 & - & - & - & 10 & 15 \\
\hline August & - & - & - & 1 & - & 1 & 2 & 9 & 15 & 20 & 1 & - & - & 45 & 9 & 3 & 19 & 4 & 3 & - & 38 \\
\hline September & 1 & - & 1 & 5 & 1 & 1 & 9 & 18 & 14 & 4 & 3 & - & - & 39 & 17 & 2 & - & 2 & - & - & 21 \\
\hline October & - & 5 & 7 & 12 & 9 & 2 & 35 & 13 & 10 & 4 & - & - & - & 27 & 4 & 4 & - & - & 2 & - & 10 \\
\hline November & 1 & 3 & 17 & 18 & 4 & 6 & 49 & 10 & 5 & 2 & - & - & - & 17 & 8 & 14 & 1 & 1 & - & - & 24 \\
\hline December & 8 & 12 & 19 & 21 & 2 & - & 62 & 2 & - & - & - & - & - & 2 & 5 & 6 & 3 & 1 & - & - & 15 \\
\hline January & 17 & 11 & 14 & 9 & 3 & - & 54 & - & 4 & - & - & - & - & 4 & 6 & 1 & 3 & 1 & - & - & 11 \\
\hline February & - & 3 & 21 & 13 & 5 & - & 42 & 4 & 2 & - & - & - & - & 6 & 6 & 3 & 3 & - & - & 3 & 15 \\
\hline March & 1 & 1 & 8 & 10 & 8 & 1 & 29 & 5 & 7 & 4 & - & - & - & 16 & 7 & 23 & 1 & - & - & - & 31 \\
\hline April & - & - & - & 5 & 2 & - & 7 & 6 & 11 & 10 & 5 & 1 & - & 33 & 7 & 9 & 4 & 1 & - & - & 21 \\
\hline May & - & - & - & 3 & 1 & 3 & 7 & 12 & 15 & 30 & 2 & 6 & - & 65 & 8 & 3 & 6 & 3 & - & - & 20 \\
\hline June & - & - & - & 1 & 3 & 4 & 8 & 7 & 7 & 26 & 4 & 3 & - & 47 & - & - & 10 & 5 & - & - & 15 \\
\hline July & 1 & - & - & 4 & 1 & - & 6 & 10 & 14 & 14 & - & 1 & - & 39 & 17 & - & 4 & 1 & - & - & 22 \\
\hline
\end{tabular}


reproductive thalli were mature and senescing (Hansen \& Doyle 1976).

Densities of Prionitis lanceolata varied from less than 20 thalli $\mathrm{m}^{-2} \mathrm{mo}^{-1}$ during summer to 160 thalli $\mathrm{m}^{-2}$ $\mathrm{mo}^{-1}$ during winter (Fig. 1). Small thalli (Size Class 1)

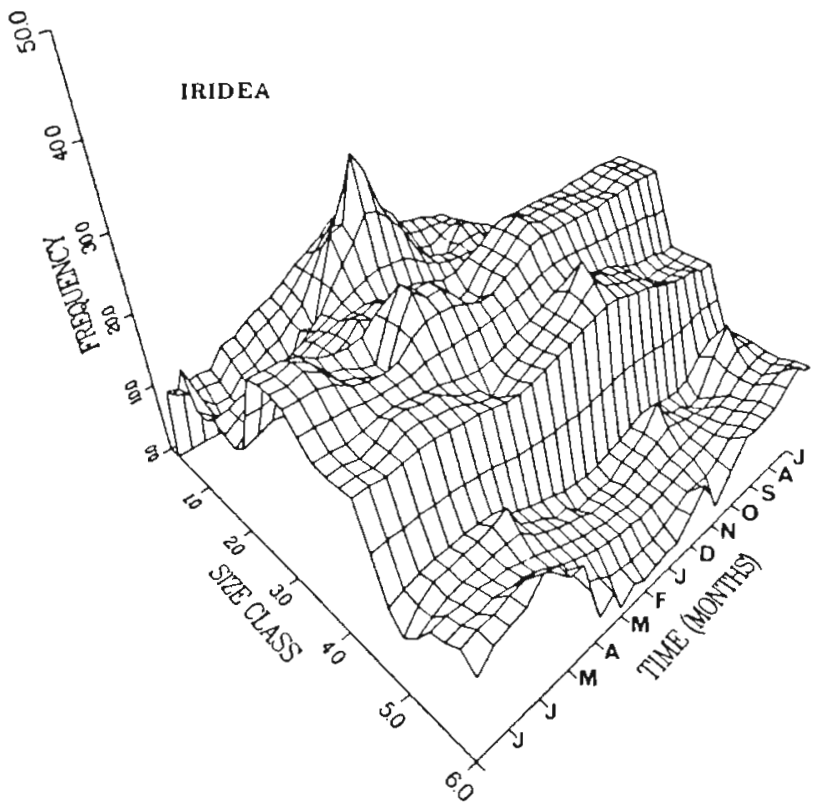

Fig. 3. Iridea cordata. Size class distribution during the sampling period. Time (mo) from July (J) 1984 to July 1985; size classes from 1 (smallest) to 6 (largest)

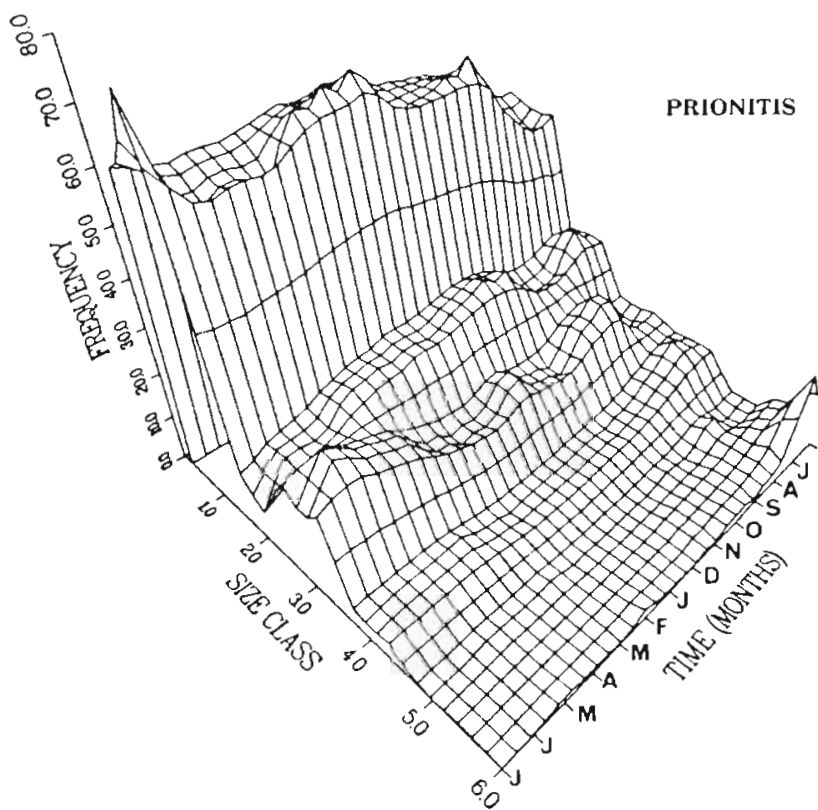

Fig. 4. Prionitis lanceolata. Size class distribution during the sampling period. Time (mo) from July (J) 1984 to Jul 1985; size classes from 1 (smallest) to 6 (largest) were dominant throughout the year (Fig, 4). Larger thalli (Size Classes 4, 5 and 6) occurred only during July and August 1984, not repeated in 1985. Tetrasporangial thalli were more common during autumn, winter and spring and poorly represented during summer (Table 1). The tetrasporangial thalli were small in size except during spring. Carposporangial thalli were in Size Classes 1 to 3 and were found throughout the year

\section{Epiphyte population structure}

A total of 2674 host thalli were observed throughout the 13 mo of sampling; 1221 (46\%) were recorded with epiphytes. The percentage of each host species with epiphytes (Fig. 5) showed differences in distribution of epiphytes between the host species. Thalli of Prionitis lanceolata had the highest percentages of epiphytes (76 to $98.5 \%$ of host plants sampled) throughout the year. Odonthalia floccosa was less heavily epiphytized ( 0 to $71 \%$ ), with a distinct summer-autumn maximum (July to November 1984, June 1985) and winter-spring minimum (December 1984 to May 1985). Iridea cordata had intermediate percentages of epiphytes ( 7 to $77 \%$ ), highest in autumn and lowest in spring and summer.

Epiphyte distribution on host thalli was found to be highly contagious (negative binomial distribution). Thus the conversion of these data to numbers of epiphytes per

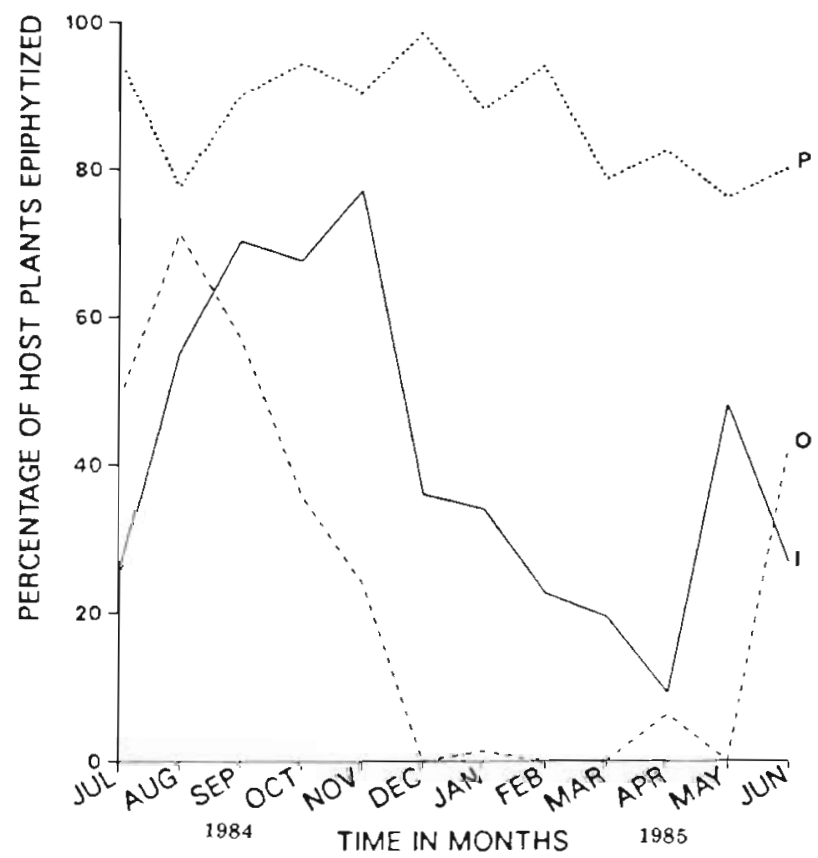

Fig. 5. Change in percentage of host plants epiphytized during the sampling period. I: Iridea cordata; $O$ : Odonthalia Hoccosa; P: Prionitis lanceolata 
surface area of host tissue also multiplied the large standard errors (Green 1976), obscuring differences between host species. Therefore, epiphyte densities have been presented per host thallus. There are differences in density of epiphytes (Fig. 6) between the 3 host species. Prionitis lanceolata had the highest mean densities of epiphytes (between 17 and 55 per host thallus), Iridea cordata was intermediate ( 3 to 17 per host thallus), and Odonthalia floccosa was lowest (0 to 10 per host thallus). Epiphytes on $O$. floccosa had a distinct seasonal variation in density with maxima in late summer and autumn and minima in winter and spring.

Of the epiphyte population $3.5 \%$ were reproductive on Prionitis lanceolata and Iridea cordata and $7.5 \%$ on Odonthalia floccosa. Reproductive thalli of $M$. coulteri were more common on $P$. lanceolata in winter than summer (Fig. 7). No reproductive epiphytic thalli were found on $I$. cordata during summer 1985. Maximum densities of reproductive epiphyte thalli occurred in winter and early spring. On Odonthalia floccosa reproductive epiphytes occurred in summer and early autumn (June to September 1984).

Loadings of original variables on PCA Axes 1 and 2 are shown in Fig. 8. The first axis (PCA 1) was a measure of overall epiphyte population abundance

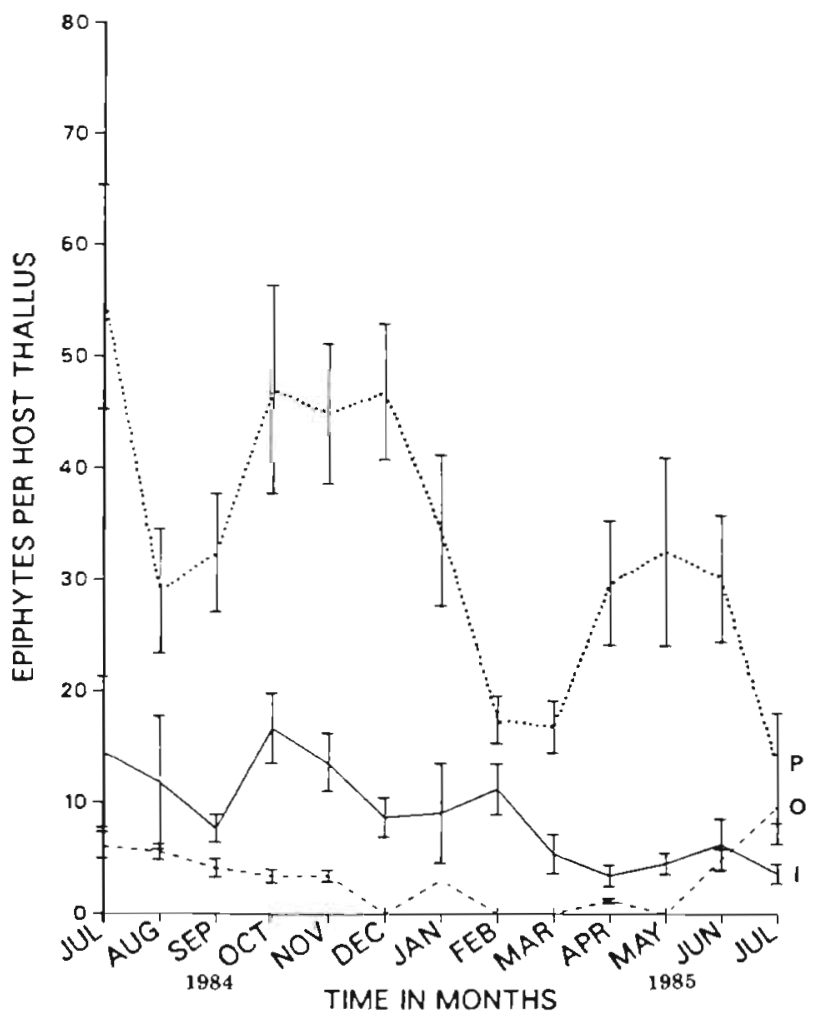

Fig. 6. Change in density of epiphytes per host thallus over the sampling period. I Iridea cordata; $\mathrm{O}$ : Odonthalia floccosa; $\mathrm{P}$ : Prionitis lanceolata with the highest positive values denoting greater amounts of vegetative epiphyte thalli. The second axis (PCA 2) separated reproductive from vegetative epiphyte thalli. The greater the positive loading on PCA 2 the greater the proportion of reproductive epiphytes.

PCA axis scores (Fig. 9) for Prionitis lanceolata indicated it had the highest densities of epiphytes (positive dispersion. PCA 1) as well as the greatest proportion of vegetative thalli (negative dispersion. PCA 2). More reproductive epiphyte thalli were present on $P$. lanceolata in October and November 1984 and January and February 1985. Both Odonthalia floccosa and Iridea cordata had low densities of epiphytes (negative

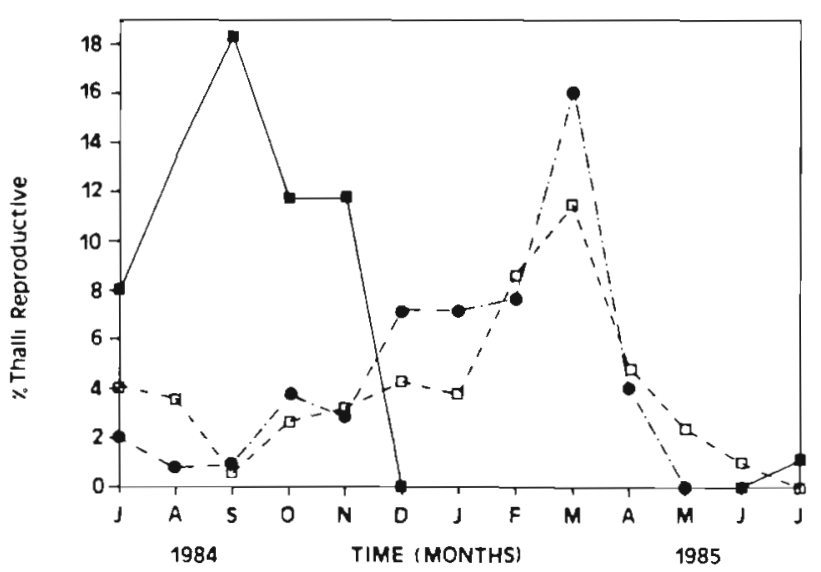

Fig. 7. Change in percentage of reproductive epiphyte thalli for each host species during the sampling period, July 1984 to July 1985. (口) Prionitis lanceolata; (-) Odonthalia floccosa; $(\bullet)$ Indea cordata

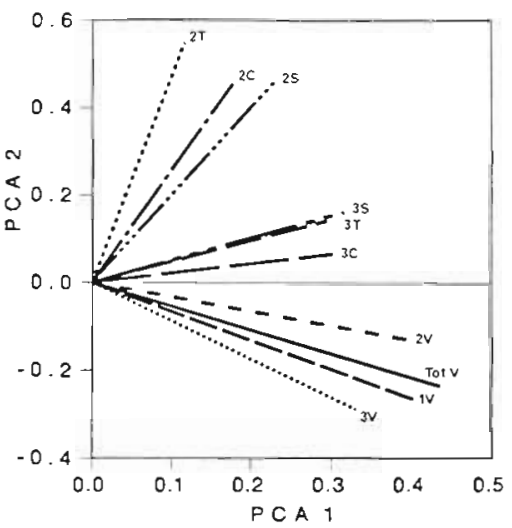

Fig. 8. Eigenvector plot of the variables for vegetative and reproductive Microcladia coulteri from all host species. Tot V: Total Epiphytes; 1V: Vegetative Size Class 1; 2V: Vegetative Size Class 2; 3V Vegetative Size Class 3; 2T: Tetrasporangial Size Class 2, 2C: Carposporangial Size Class 2; 2S: Spermatangial Size Class 2; 3T. Tetrasporangial Size Class 3; 3C: Carposporangial Size Class 3; 3S: Spermatangial Size Class 3 


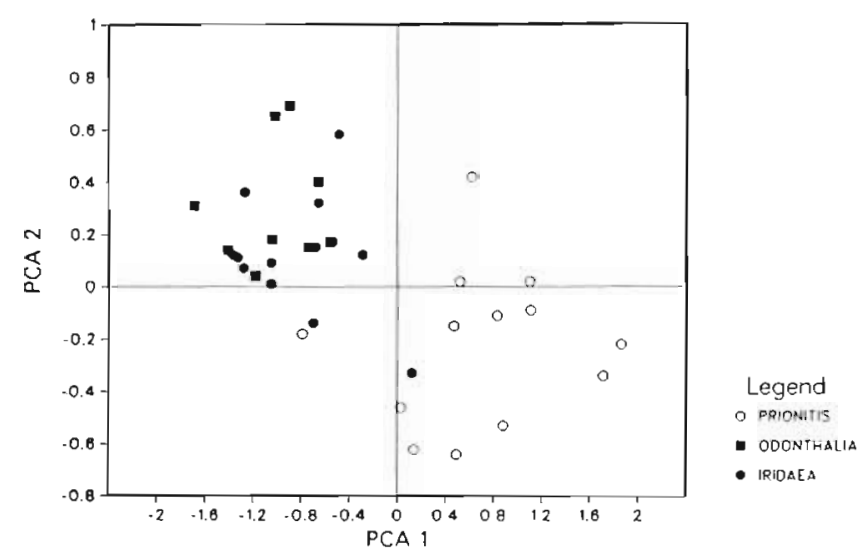

Fig. 9. Plot of the monthly means of the PCA scores of the epiphyte variables for the host species. (O) Prionitis lanceolata;

(m) Odonthalia floccosa; (•) Iridea cordata

dispersion: PCA 1) but a higher proportion of reproductive epiphyte thalli (positive dispersion: PCA 2).

Table 2 gives the partitioning of variation between terms from the nested ANOVA on PCA axis scores. The first PCA axis accounted for $40.99 \%$, the second $12.57 \%$, and the third $9.9 \%$, totalling $63.46 \%$ of the total variation in the epiphyte population structure. Seasonality of Microcladia coulteri (A) and variation in epiphyte population structure between host species $[B(A)]$ accounted for $11 \%$ of total variation. Withinhost species variation in reproductive status [C(AB)], size of host thallus $[D(A B)]$ and spatial distribution of host species $[F(A B)]$ accounted for $31.63 \%$ of the total variation in epiphyte population structure. The error term was the largest single term $(21.05 \%)$.

\section{DISCUSSION}

Microcladia coulteri persists in epiphytic populations through the utilization of different host species as sub-

Table 2. Percent variation accounted for by various sources on the first 3 PCA axes as determined by the nested ANOVA model: PCA 1, PCA 2, PCA $3=\mathrm{A}+\mathrm{B}(\mathrm{A})+\mathrm{C}(\mathrm{AB})+\mathrm{D}(\mathrm{AB})+$ $F(A B)+E$ where $P C A i=P C A$ axis score $; A=$ time $(\mathrm{mo}): B=$ host species; $C=$ reproductive status of host; $D=$ size class of host $; F=$ location along the transect; $E=$ error. Percent variation for: $\mathrm{PCAi}=\mathrm{SS}\left(\mathrm{i}_{\text {iartor }}\right) / \mathrm{SS}\left(\mathrm{i}_{\text {total }}\right) \cdot \lambda_{1} / \lambda_{\text {total }}$

\begin{tabular}{|lrrrr|}
\hline Source & PCA 1 & PCA.2 & PCA3 & Total \\
& $40.99 \%$ & $12.57 \%$ & $9.9 \%$ & $63.46 \%$ \\
\hline A & 2.75 & 0.31 & 0.48 & 3.54 \\
B(A) & 5.70 & 0.82 & 0.88 & 7.40 \\
C $(\mathrm{AB})$ & 3.30 & 0.90 & 0.54 & 4.74 \\
D(AB) & 11.15 & 2.65 & 1.57 & 15.37 \\
F(AB) & 7.60 & 2.38 & 1.54 & 11.52 \\
Error & 10.50 & 5.49 & 5.06 & 21.05 \\
\hline
\end{tabular}

strata. This is accomplished by year-round recruitment of juveniles combined with fortuitous availability of suitable host substratum. At Beaver Point, during late summer and early autumn the hosts Odonthalia floccosa and Iridea cordata were colonized heavily by $M$. coulteri. At that time both species occurred in large numbers and larger sized thalli than at other times of the year. During winter both host species overwintered as reduced basal portions or basal cushions. Prionitis lanceolata was the most available, colonizable substratum over winter and spring and contained the densest epiphytic populations of the 3 host species. It was not a major component of the benthic flora during summer. $M$. coulteri showed little host specificity at the species level, but epiphyte population structure was greatly affected by variations in size of host thalli and their spatial distribution.

Epiphyte population structure is linked to the availability of host substrata for colonization. All host species showed varying degrees of seasonality in density, size structure and reproductive output. Odonthalia floccosa was predominantly a summer alga, with higher densities, larger size classes and more reproductive thalli occurring in summer. During winter it was represented by Size Class 1 vegetative thalli, basal branches which regenerate in spring (Goff \& Cole 1976). Iridea cordata occurred throughout the year, but was characterized by blade initiation in winter, fast growth in spring, maturity in summer and senescence in autumn (Hansen 1977). More thalli were reproductive during autumn and winter whereas larger sized thalli were reproductive during spring and summer. Prionitis lanceolata had winter maxima in density, occurred predominantly as smaller size classes and was reproductive throughout the year.

Populations of Microcladia coulteri persist and reproduce throughout the year. Continuous reproduction and colonization appears to be the survival strategy. The ectocarpoid epiflora on Laminaria spp. (Russell 1983a,b) persisted through a strategy that included parallel growth with the host and reproduction before sloughing of senescent host tissue. $M$. coulteri differs only in occurring on a variety of different host species. Prionitis lanceolata had the greatest percent of epiphytized host thalli, the greatest densities of epiphytes per host thallus and the greatest amounts of the epiphyte size classes per host thallus. Superficial observation would suggest it to be the most important host species in the perpetuation of epiphytic populations of $M$. coulteri. However, a low summer density of this host, combined with high densities of Odonthalia floccosa resulted in $O$. floccosa being more important as a substratum for $M$. coulteri during the summer. Indea cordata contained intermediate densities of $M$. coulteri throughout the year. Initial colonization of the epiphyte 
was greatest on $P$. lanceolata but larger percentages of the epiphyte population on $O$. floccosa became mature and reproductive.

The partitioning of variation in the ANOVA indicated little host specificity and little seasonality in density of vegetative and reproductive thalli of Microcladia coulteri. Between-host species variation in epiphyte population structure was less than half of the variation accounted for by within-host species differences in size and spatial distribution.

Higher densities of epiphytes occurred on older portions of algal host thalli, as previously noted by Ballantine (1979). It is not surprising to find more epiphyte thalli on larger, mature or senescing host thalli. To quantify this for Microcladia coulteri on all 3 host species studied supports the premise that $M$. coulteri is capable of utilizing a variety of available substrata.

Higher densities of epiphytes on older host tissue can represent more colonizing events by the epiphyte. Erect thalli of Prionitis lanceolata persist for 6 to $9 \mathrm{mo}$ (Dethier 1982) and Iridea cordata for 9 to 12 mo (Hansen 1977). Visible Size Class 1 epiphytes took $23 \mathrm{~d}$ to develop on $I$. cordata in mid-winter (Kendrick 1986). Three to 5 generations of epiphytes could be produced over the lifespan of these host species. Also, changes in surface texture, chemistry or charge with age of host thalli (Linskens 1966, Niehof \& Loeb 1974) and changes in the hydrodynamic environment with increased size of host thalli (Vogel 1981, Nowell \& Jumars 1984) may affect rates of settlement and adhesion of spores. Decreases in epiphyte densities near meristematic regions as shown by D'Antonio (1985) and Ballantine (1979) were also observed in this study.

Both host and epiphyte species exhibit highly contagious spatial distributions. The contagious distribution of host species along the transect implies that the post-disturbance patch size for successful establishment of the host species is smaller than the transect length $(50 \mathrm{~m})$ but larger than the quadrat size $\left(0.25 \mathrm{~m}^{2}\right)$. The contagious distribution of the epiphytes on the host thalli suggests the location of an epiphyte on a host thallus increases the probability that subsequent epiphytes will develop on that thallus (adapted from Thomas 1977). Growth of one epiphyte thallus could enhance the settlement of other spores of that epiphyte species through development of turbulent eddies around the existing epiphyte (Munteanu \& Maley 1981, Medlin 1983) or chemical attractants from the existing epiphyte, as observed in gametes of the Phaeophyta (Boland et al. 1984, Muller et al. 1985). Continued settlement of epiphyte spores may also be assisted by the proximity of reproductive epiphyte thalli (maturity of initial colonizers).

Although Microcladia coulteri is found predominantly as an epiphyte on other macro-algae no phy- siological relationship need be inferred for its persistence. The population structure of $M$. coulteri on 3 taxonomically different host species showed visibly different epiphyte loading, yet more variation in the epiphyte population structure occurred within host species. Seed \& O'Connor (1981) noted '... the importance of resource generation (host growth) as an alternative to the disturbance and competitive network paradigms... in the structuring of epiphytic faunal communities. Although other factors such as light, temperature and nutrients affect the growth of epiphytes, the availability of suitable host substrata is also important. One mechanism for epiphyte persistence where the spatial and seasonal availability of host substrata is patchy is in the utilization of a variety of host substrata as shown by $M$. coulteri.

Acknowledgements. This research was supported by Canadian NSERC Operating Grant U-0318 (to M.W.H.). Many thanks to Jack Maze, Rob De Wreede, Gary Bradfield and Rick Gould for their assistance and discussion in sampling design, data analysis and review of the research. Also a heartfelt thanks to Di Walker for comprehensively reviewing the paper We are also thankful for the comments of 2 anonymous reviewers that improved this manuscript greatly.

\section{LITERATURE CITED}

Abbott, I. A., Hollenberg, G. J. (1976). Marine algae of California. Stanford Univ. Press, Stanford

Ballantine, D. L. (1979). The distribution of algal epiphytes on macrophyte hosts offshore from La Parguera, Puerto Rico. Botanica mar. 22: 107-110

Ballantine, D. L. Humm, H. J. (1975). Benthic algae of the Ancote Estuary: epiphytes on seagrass leaves. Fla Scient. 38: $150-162$

Boland, W., Jzenicke, L., Muller, D. G., Peters, A. (1984). Distribution of algal chemoreceptors: A comparative receptor study with two seaweed pairs: Cutilaria multifidaf Syringoderma phinneyi and Desmarestia aculeatal Ectocarpus siliculosus (Phaeophyceae). Eur J. Biochem. 144: 169-176

Campbell, N. A (1980). Robust procedures in multivariate analysis. I. Robust covariance estimation. Appl. Statist. 29: 231-237

D'Antonio, C. (1985). Epiphytes on the rocky intertidal red alga, Rhodomela larix (Turner) C. Agardh: negative effects on the host and food for herbivores? J. exp. mar. Biol. Ecol. 86: $197-218$

Dethier, M. N. (1982). Pattern and process in tidepool algae: factors influencing seasonality and distribution. Botanica mar 25: 55-66

De Wreede, R. E. (1984). Growth and age class distribution of Pterygophora californica (Phaeophyta). Mar. Ecol. Prog. Ser. 19: 93-100

Goff, L. J., Cole, K. (1976). The biology of Harveyella mirabilis (Cryptonemiales, Rhodophyceae) IV Life history and phenology. Can. J. Bot. 54: 281-292

Green, R. H. (1976). Sampling design and statistical methods for environmental biologists. Wiley Interscience, New York

Hannach, G., Santelices, B. (1985). Ecological differences 
between the isomorphic reproductive phases of two species of Iridaea (Rhodophyta, Gigartinales). Mar Ecol. Prog. Ser 22: 291-303

Hansen, J. E. (1977). Ecology and natural history of Iridaea cordata (Gigartinales, Rhodophyta): growth. J. Phycol. 13: 395- 402

Hansen, J. E. Doyle, W. T (1976). Ecology and natural history of Iridaea cordata (Rhodophyta, Gigartinaceae): population structure. J. Phycol. 12: 273-278

Harlin, M. M. (1980). Seagrass epiphytes. In: Phillips, R. C., McRoy, C. P. (eds.) Handbook of seagrass biology: an ecosystem perspective. Garland S.T.P.M. Press, New York, p. 151-171

Kendrick, G. A. (1986). The epiphyte Microcladia coulteri: Changes in population structure with spatial and temporal variation in availability of host species. M. Sc. thesis. Univ. of British Columbia, Vancouver

Kain, J. M. (1982). The reproductive phenology of nine species of Rhodophyta in the subtidal region of the Isle of Man. Br. Phycol. J. 17: 321-331

Lewis, A. E. (1966). Biostatistics. Reinhold Publ. Corp, New York

Linskens, H. F. (1966). Adhaesion von Fortpflanzungszellen benthonischer Algen. Planta (Berl.) 68: 99-110

Medlin, L. K. (1983). Community analysis of epiphytic diatoms from selected species of macroalgae collected along the Texas coast of the Gulf of Mexico. Ph. D. thesis, Texas A\&M Univ., College Station

Muller, D. G., Maier, I., Gassmann, G. (1985). Survey of sexual pheromone specificity in Lamiariales (Phaeophyceae). Phycologia 24: 475-477

Munteanu, N., Maley, E. J. (1981). The effect of current on the distribution of diatoms settling on submerged glass slides. Hydrobiologia 78: 273-282
Niehof, R., Loeb, G. (1974). Dissolved organic matter in seawater and the electric charge of immersed surfaces. J. mar. Res. 32: 5-12

Norall, T. L., Mathieson, A. C., Kilar, J. A. (1981). Reproductive ecology of four subtidal red algae. $J$ exp mar Biol. Ecol. 34: 119-136

Nowell, A. R. M., Jumars, P. A. (1984). Flow environments of aquatic benthos. Ann. Rev. Ecol. Syst. 15: 303-328

Pocock, D. C. D., Wisharf, D. (1969). Methods of deriving multi-factor uniform regions. Trans. Inst. Br. Geographers 47: 73-98

Russell, G. (1983a). Formation of an ectocarpoid epiflora on blades of Laminaria digitata. Mar. Ecol. Prog. Ser. 11: 181-187

Russell, G. (1983b). Parallel growth patterns in algal epiphytes and Laminaria blades. Mar. Ecol. Prog. Ser 13: 303-304

Scagel, R. F., Garbary, D. J., Golden, L., Hawkes, M. W. (1986). A synopsis of the benthic marine algae of British Columbia, northern Washington and southeast Alaska. Phycological Contribution No. 1, Dept. of Botany, University of B.C., Vancouver

Seed, R., O'Conner, R. J. (1981). Community organization in marine algal epifaunas. Ann. Rev. Ecol. Syst. 12: 49-74

Thomas, R. W (1977). An introduction to quadrat analysis. Concepts and Techniques in Modern Geography 12: $18-25$

Vogel, S. (1981). Life in moving fluids: the physical biology of flow. Willard Grant Press, Boston

Whittick, A. (1983). Spatial and temporal distributions of dominant epiphytes on the stipes of Laminaria hyperborea (Gunn.) Fosl. (Phaeophyta: Laminariales) in S.E. Scotland. J. exp. mar. Biol. Ecol 73: 1-10

Zar, J. H. (1974). Biostatistical analysis. Prentice-Hall, New Jersey 